\title{
Gasol-treated barley for pigs
}

\author{
TIMO ALAVIUHKOLA ${ }^{1}$ and MATTI NÄSI ${ }^{2}$ \\ 1 Agricultural Research Centre, Swine Research Station, \\ SF-05840 HYVINKÄ $\ddot{A}$ \\ 2 University of Helsinki, Department of Animal Husbandry \\ SF-00710 HELSINKI
}

\begin{abstract}
Moist barley (GB) preserved with Gasol additive (containing formaldehyde, acetic acid, isobutyric acid and lignosulphonates) was evaluated as pig feed. A digestibility trial was conducted as a $3 \times 3$ Latin square, in which dried barley (DB) was replaced with GB at two levels, 50 and $100 \%$. The performance and carcase properties were examined in a feeding trial with 48 growing pigs fed on either DB or GB supplemented with protein concentrate. Gasol barley showed no signs of deterioration during storage (DM $79 \%$, average application level $1.0 \%$ ). The lysine content was lower in GB than in DB, $2.3 \mathrm{vs.} 3.9 \mathrm{~g} / 16 \mathrm{~g} \mathrm{~N}$ and sulphuric amino acids and threonine were also lower. GB had lower digestibilities for OM, CP and NFE: $78.9,68.8$ and $86.9 \%$ vs. $82.0,75.6$ and 88.6 in $\mathrm{DB}(\mathrm{P}>0.05)$. The amino acid digestibilities of the GB averaged $88 \%$ of the values of the $\mathrm{DB}$ diet $(\mathrm{P}>0.05)$. The estimated feed values for GB and DB were, respectively 1.05 and $1.09 \mathrm{FU} / \mathrm{kg} \mathrm{DM}$ and 85 and $86 \mathrm{~g} \mathrm{DCP} / \mathrm{FU}$. On the GB diet, the pigs gained significantly less $(\mathrm{P}<0.01)$ than on the DB diet $(589 \mathrm{vs} .703 \mathrm{~g} / \mathrm{d})$ and FCE was poorer, 3.46 vs. $2.89 \mathrm{~kg} \mathrm{DM} / \mathrm{kg}$ gain $(\mathrm{P}<0.01)$. The firmness of the fat and colour of the lean were inferior in the pigs fed on GB $(\mathrm{P}>0.05)$. The results showed that Gasol is unsuitable for preserving grain intended for pig feed if the grain is uncontaminated, but moulded barley can be treated with Gasol to reduce the detrimental effects of the fungal toxins.
\end{abstract}

Index words: Moist grain preservation, barley, pig feeding

\section{Introduction}

Organic acids and formaldehyde inhibit microbial growth on high-moisture grains, which allows the grains to be stored aerobically and thus offers an alternative to the conventional drying process. When highmoisture barley treated with organic acids was fed to growing pigs and compared with a dried barley ration with the same dry matter content, its feeding value was reported to be the same (Alaviuhrola 1973, Cole et al. 1975, 
1980, Pringle et al. 1983) or a little less (Thomke and TIDEN 1973). "GASOL" is a new grain preservative developed for use in ruminant feeding by Farmos-Group Ltd. Gasol solution contains $15 \%$ formaldehyde and acetic acid, isobutyric acid and lignosulphonates. It has given promising results when used against the fungus Fusarium graminearum and has reduced the detrimental effects of the toxin zearaleone produced by this fungus (Kallela and SAastamoinen 1982).

The objective of this study was to determine the feeding value of Gasol-preserved highmoisture barley for growing pigs, as measured by the nutrient digestibilities, pig performance and carcase properties.

\section{Materials and methods}

Barley var. Pomo was harvested and part of it was dehydrated in a warm air dryer, the remainder being preserved with Gasol liquid. The level of application of Gasol was chosen according to the moisture content of the barley, as follows:

$\begin{array}{cc}\text { Moisture } & \text { Gasol application } \\ \% & 1 / \text { tn } \\ 20 & 9.5 \\ 22 & 10.5 \\ 24 & 12.0 \\ 30 & 16.5\end{array}$

Before storing the dry matter of the barley averaged $75 \%$. According to visual inspection, the preserved barley showed no signs of spoiling. The barley was milled in a hammer mill, using a $3 \mathrm{~mm}$ sieve.

The digestibility and balance trial was carried out with three castrated Landrace pigs weighing $35-67 \mathrm{~kg}$. The total collection method was used and the experiment was designed as a $3 \times 3$ Latin square, in which dried barley was replaced with Gasol preserved barley at two levels, 50 and $100 \%$. The diets were enriched with $15 \%$ of skim milk powder, a mineral mixture, $40 \mathrm{~g} / \mathrm{d}$, and a vitamin mixture, $15 \mathrm{~g} / \mathrm{d}$. The crude protein content of the diets was $16.5 \%$ of DM. The daily rations in the different periods were 2.0, 2.2 and 2.6

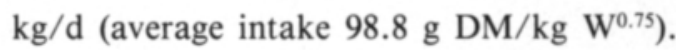
The transition period between diets was four days and the standardization and collection periods were both six days. The details of the procedures of feeding and faeces collection are described by NÄsı (1982).

In the feeding experiment, 48 pigs were allocated to two groups, of which one was fed with dry barley (DB) and the other received Gasol preserved barley (GB). The two groups received the same daily amount of protein concentrate, composed of fish meal $40 \%$, soybean meal $25 \%$ and mineral and vitamin mixture $35 \%$. The DCP content of the protein concentrate mixture was $36.7 \%$, and the supplementation level was $10 \%$ of the airdried feed. The two groups were intended to receive an equal amount of barley dry matter daily. The dry matter content of the dehydrated barley averaged 86.6 and that of the Gasol barley $79.0 \%$. There was sufficient Gasol barley to feed 16 pig for the whole experimental period.

The chemical analyses of the feeds and faeces were performed according to the official procedures. Amino acids were determined with a Technicon TSM autoanalyzer after hydrolysis of 20 hours in $6 \mathrm{~N} \mathrm{HCl}$. The volatile fatty acids of Gasol barley were determined by gas-liquid chromatography.

\section{Results and discussion}

The chemical composition of the experimental feeds is presented in Table 1. The Gasol-treated barley contained acetic acid 1.97 $\mathrm{g}$ and isobutyric acid $2.82 \mathrm{~g} / \mathrm{kg}$, which were residues from the preservative. The lactic acid content was $0.56 \mathrm{~g} / \mathrm{kg}$, indicating slight fermentation during storage. The GB showed no visible spoilage and smelled fresh. Its $\mathrm{NH}_{3}-\mathrm{N}$ content was found to be quite low, $0.04 \mathrm{~g} / \mathrm{kg}$. The lysine content was reduced during storage to $2.3 \mathrm{~g} / 16 \mathrm{~g} \mathrm{~N}$, as against $3.3 \mathrm{~g}$ in dried barley. The GB also had lower contents of sulphur amino acids (3.9 vs 3.4 ), threonine (3.7 vs 3.5$)$ and arginine (4.4 vs 3.7$)$. Protein treated with formaldehyde has been shown to 
Table 1. Chemical composition and nutrient digestibilities of dried barley and Gasol preserved barley fed to pigs and estimated feed values.

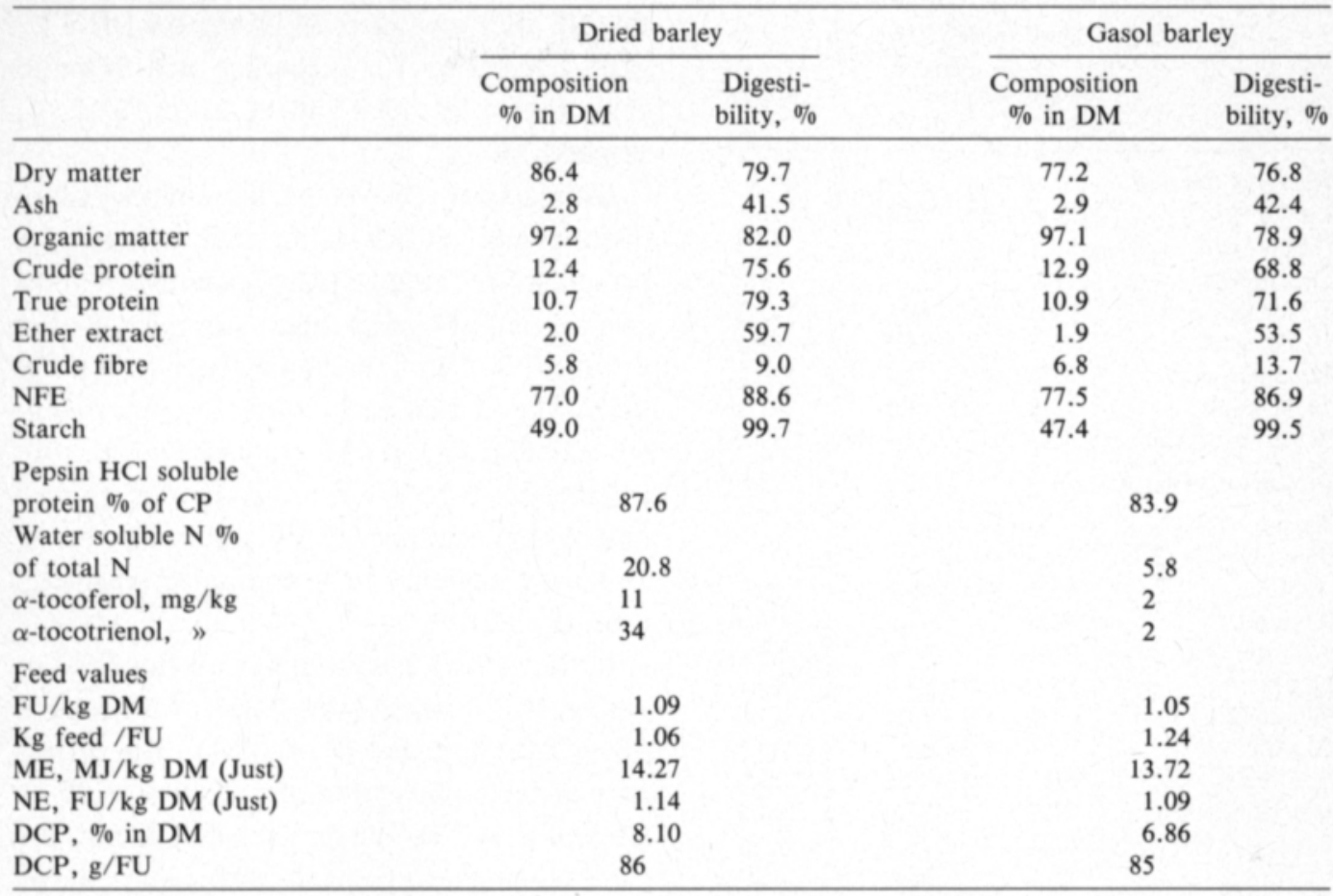

have a reduced content of lysine (HOVE and LOHREy 1976, KowalczyK and OTWINOWSKA 1983). The content of $\alpha$-tocoferol and $\alpha$ tocotienol was lower in GB than in DB (4 $\mathrm{mg} / \mathrm{kg}$ vs $45 \mathrm{mg} / \mathrm{kg}$ ).

The apparent nutrient digestibilities were lower in GB than in DB: by $3.1 \%$ units for organic matter, $6.8 \%$ units for crude protein and $1.7 \%$ units for NFE (Table 1). The differences were not statistically significant $(\mathrm{P}>0.05)$. The digestibility of starch was complete and similar in both grains $(99.7 \%$ vs $99.5 \%$ ). In $\mathrm{GB}$ the pepsin $\mathrm{HCl}$ solubility of crude protein was lower and the watersoluble fraction of total nitrogen was greatly reduced (Table 1). Experiments with pigs, rats and chicks have indicated that treatment with formaldehyde reduces the digestibility of protein (Thomas et al. 1979, SpEARs et al. 1980, KoWACZYK and OTWINOWSKA 1983). However, treatment of soybean meal with low levels of formaldehyde, $0,3-0.4 \%$, did not affect the performance of rats and chicks (Hove and LOHREY 1976, SPEARS et al. 1980). Formaldehyde treatment reduces protein degradability by rumen microbes and improves nitrogen utilization and performance in ruminants, but high concentrations reduce the digestibility of total protein (KAUFMANN and LuPPING 1982, Kowaltczyk et al. 1982). Huhtanen (1984) found that the degradation rates of DM, crude protein and starch determined by the nylon bag technique were lower in GB than in propionic acid barley. The degradation of crude protein in 9 hours was $46.6 \%$ for GB and $76.4 \%$ for PAB.

The feed values calculated for DB and GB are presented in Table 1. In DB the net energy value was $3.7 \%$ higher and that for metabolizable energy $3.9 \%$ higher than in GB.

The nitrogen balance measurements are shown in Table 2. Nitrogen retention was on average $5.9 \%$ lower in pigs fed on GB than in pigs fed on DB. Nitrogen utilization, mea- 
Table 2. Nitrogen balance, protein utilization and amino acid apparent digestibilities of diets in which dried barley (DB) was replaced with Gasol preserved barley (GB).

\begin{tabular}{|c|c|c|c|}
\hline & DB $100 \%$ & $\begin{array}{l}\text { DB } 50 \% \\
\text { GB } 50 \%\end{array}$ & GB $100 \%$ \\
\hline \multicolumn{4}{|l|}{ Nitrogen balance } \\
\hline Intake, $\mathrm{g} / \mathrm{d}$ & 51.6 & 53.5 & 54.2 \\
\hline Faeces, g/d & 12.3 & 15.2 & 16.9 \\
\hline Digestibility, \% & 76.0 & 71.7 & 69.0 \\
\hline Absorbed, g/d & 39.3 & 38.3 & 37.3 \\
\hline Urine, $\mathrm{g} / \mathrm{d}$ & 15.7 & 16.1 & 15.2 \\
\hline Retained, g/d & 23.6 & 22.2 & 22.2 \\
\hline$\%$ of intake & 45.8 & 41.5 & 41.2 \\
\hline$\%$ of absorption & 60.3 & 57.9 & 59.5 \\
\hline Biological value & 73.9 & 72.7 & 74.3 \\
\hline \multicolumn{4}{|l|}{$\begin{array}{l}\text { Amino acid } \\
\text { digestibilities }\end{array}$} \\
\hline Alanine & 65.4 & 59.7 & 56.9 \\
\hline Arginine & 80.6 & 71.6 & 65.8 \\
\hline Aspartic acid & 71.7 & 67.8 & 65.1 \\
\hline Cystine & 85.0 & 74.4 & 65.1 \\
\hline Glutamic acid & 87.6 & 84.1 & 80.9 \\
\hline Glycine & 71.1 & 65.2 & 60.1 \\
\hline Histidine & 83.2 & 79.8 & 76.6 \\
\hline Isoleucine & 77.1 & 73.8 & 70.9 \\
\hline Leucine & 81.4 & 78.9 & 75.0 \\
\hline Lysine & 72.4 & 66.6 & 62.9 \\
\hline Methionine & 82.8 & 82.8 & 79.6 \\
\hline Phenylalanine & 81.1 & 77.3 & 74.5 \\
\hline Proline & 89.9 & 87.7 & 85.5 \\
\hline Serine & 82.1 & 77.6 & 74.5 \\
\hline Threonine & 76.0 & 72.1 & 69.6 \\
\hline Tyrosine & 77.4 & 77.5 & 66.8 \\
\hline Valine & 78.8 & 74.6 & 71.9 \\
\hline
\end{tabular}

sured as percentage retention of absorbed nitrogen, was also lower on a GB diet (differences not significant, $\mathrm{P}>0.05)$. This indicates poorer balance of the amino acids ab- sorbed from the intestinal tract. Loss of lysine occurred during storage. The lysine intake on the GB diet averaged 14.2 and on DB 17.2 $\mathrm{g} / \mathrm{d}$. The values for threonine and S-amino acids were $12.9,12.9$ and 11.5 and $12.1 \mathrm{~g} / \mathrm{d}$, respectively.

Estimates of the average digestibilities of individual amino acids on the different diets are presented in Table 2. The apparent faecal digestibilities of amino acids on the GB diet averaged $89 \%$ of the values found on a DB diet. The differences were not significant $(\mathrm{P}>0.05)$. Lysine, for example was less digestible by $9.5 \%$ units on GB diet, which means that the mean daily amount of lysine absorbed was only $8.9 \mathrm{~g}$ compared with 12.5 $\mathrm{g}$ on the DB diet.

In the growth trial the pigs on the GB diet gained $16 \%$ slower ( $589 \mathrm{vs} 703 \mathrm{~g} / \mathrm{d}$ ) than the pigs on the DB diet $(\mathrm{P}<0.01)$. The difference in feed conversion efficiency was $20 \%$ $(\mathrm{P}<0.01)$. The decreased leanness of the carcases of the pigs in the GB group shows the inferior quality of the protein (Table 3). The protein level was rather low $(120 \mathrm{~g} \mathrm{DCP} /$ FU) in respect to get information of the effect of the preservation on the protein quality. Growing pigs of the lean type require $13 \%$ DCP in their diet (SALo et al. 1982).

As regards the carcase characteristics, the firmness of the fat and colour of the lean were inferior in the animals of the GB group to those in the control group.

The results in both the digestibility and balance and the growth trials showed that

Table 3. Performance and carcase properties of pigs fed on dried or Gasol preserved barley.

\begin{tabular}{lccc}
\hline & Dried barley & Gasol barley & Significance \\
\hline No of pigs & 24 & 16 & $\mathrm{NS}$ \\
Initial live weight, $\mathrm{kg}$ & 25.5 & 25.3 & $\mathrm{NS}$ \\
Final live weight, kg & 91.0 & 90.0 & $\mathrm{NS}$ \\
Slaughter weight, kg & 65.5 & 64.9 & $\mathrm{NS}$ \\
Slaughter loss, \% & 28.0 & 28.7 & $\mathrm{NS}$ \\
Daily gain, g, corr. & 703 & 589 & $\mathrm{P}<0.01$ \\
Days in experiment & 93.5 & 111.4 & $\mathrm{P}<0.01$ \\
Feed DM kg/kg gain & 2.89 & 3.46 & $\mathrm{P}<0.01$ \\
Side fat, mm & 17.2 & 15.5 & $\mathrm{NS}$ \\
Meat $\%$ in valuable cuts & 80.5 & 79.0 & $\mathrm{NS}$ \\
Fat firmness & 12.8 & 11.8 & $\mathrm{P}<0.01$ \\
Meat colour (Göfo values) & 57 & 54 & $\mathrm{NS}$ \\
\hline
\end{tabular}


Gasol solution is not promising as a preservative for grain intended for use in pig feeding. If the grain is moulded, however, the detrimental effects of the toxin zearaleone can be diminished by using Gasol (KALLELA and
SAASTAMOINEN 1982). When grain treated in this way is used in pig feeding the quality of the protein should be improved, e.g. by supplementation with synthetic lysine and vitamin E.

\section{References}

Alavıuhrola, T. 1983. Săilöviljaa lihasioille. Kăytănnön Maamies 8: 40-41.

Cole, D.J.A., Brooks, P.H., English, P.R., LivingSTONE, R.M. \& Luscombe, J.R. 1975. Propionic acidtreated barley in the diets of bacon pigs. Anim. Prod. 21: 295-302.

-, Williams, I.H., English, P.R. \& Luscombe, J.R. 1980. A note on propionic acid-treated barley of different moisture contents in the diets of growing pigs. Anim. Prod. 31: 213-215.

Hove, E.L. \& Lohrey, E. 1976. The effects of formaldehyde on the nutritive value of casein and lactoalbumin in the diets of rats. J. Nutr. 106: 382-387.

Huhtanen, P., Poutiainen, E. \& Mikkola, T. 1985. The effect of supplementation of grass silage with rapeseed meal or Gasol-treated barley on the performance of growing cattle. J. Agric. Sci. Finl. 57: 75-84.

Kallela, K. \& SaAstamoinen, I. 1982. The effects of Gasol grain preservative dosages on the growth of Fusarium graminearum and the quality of the toxin Zearaleone. Nord. Vet.-Med. 34: 124-129.

Kaufmann, W. \& Lupping, W. 1982. Protected proteins and protected amino acids for ruminants. Protein contribution for ruminants. Ed. Miller, E.L., Pike, I.H. \& van Es, A.J.H. p. 36-75. Butterworths.

Kowalczyk, J. \& Otwinowska, A. 1983. Digestion of pigs diets with formaldehyde-treated rapeseed oilmeal. Z. Tierphysiol., Tierernährg. u. Futtermittelkde. 49:

\section{SELOSTUS}

\section{Gasol-käsitelty ohra sikojen rehuna}

Timo Alaviuhkola ja Matti Näsi

Maatalouden tutkimuskeskus, sikatalouden

tutkimusasema, 58400 Hyvinkää ja

Helsingin yliopisto, kotieläntieteen laitos, $00710 \mathrm{Helsinki}$

Sulavuus- ja tasekokeessa sekä kasvatuskokeessa selvitettiin Gasol säilöntäaineen (sis. formaliinia, etikka- ja isovoihappoa sekă lignosulfonaattiliuosta) soveltuvuut-

$38-43$.

—, Robinson, J.J. \& OtwinowsKa, A. 1982. The digestion in the small intestine of young bulls of protein of rapeseed meal treated or untreated with formaldehyde. Anim. Feed Sci. Technol. 7: 225-232.

NÄsı, M. 1982. Nutritive value of Eurolysine bacterial protein and Pekilo protein for growing pigs. J. Scient. Agric. Soc. Finl. 54: 263-269.

Pringle, D., Beammes, R.M., Tait, R.M. \& Litsky, J. 1983. Effects of storage and processing of barley on its utilization by pigs and rats. Anim. Feed Sci. Technol. 9: $89-97$.

SAlo, M.-L., TuORI, M. \& KiISKInen, T. 1982. Rehutaulukot ja ruokintanormit. Helsinki $70 \mathrm{p}$.

Spears, J.W., Hatfield, E.E. \& Clark, J.H. 1980. Influence of formaldehyde treatment of soybean meal on performance of growing steers and protein availability in the chick. J. Anim. Sci. 50: 750-755.

Thomas, E., Trenkle, A. \& Burroughs, W. 1979. Evaluation of protective agents applied to soybean meal and fed to cattle I. Laboratory measurements. J. Anim. Sci. 49: $1337-1345$.

ThомкE, S. \& Tiden, A. 1973. Moist barley treated with propionic, acetic acid in rations to growing pigs. Swedish J. Agric. Res. 3: 145-151.

Ms received September 10, 1985 ta sioille syötettăvăn ohran tuoresäilontāaineeksi. Gasol säilötty vilja oli silmämääräisesti tarkasteltuna săilynyt moitteettomasti. Kuiva-ainepitoisuus oli keskimäărin 
$75 \%$ sảilöttäessä. Gasol-ohran lysiinipitoisuus oli alentunut săilönnăn vaikutuksesta $2.3 \mathrm{~g}: \mathrm{aan} / 16 \mathrm{~g} \mathrm{~N}$, kun se oli kuivatussa ohrassa $3.9 \mathrm{~g}$, samoin rikkipitoisten aminohappojen ja treoniinin pitoisuudet olivat alentuneet. Gasol-ohran sulavuudet olivat huonompia kuin kuivatun ohran: raakavalkuainen $68.8 ; 75.6$, orgaaninen aine 78.9 ; 82.0 ( $\mathrm{P}>0.05$ ). Lasketuiksi rehuarvoiksi saatiin 1.05 ry/kg ja 85 g srv/ry Gasol-ohralle ja 1.09 ja 86 kuivalle ohralle. Kasvatuskokeen tulokset olivat yhdenmukaiset, lisăkasvu jäi merkitsevăsti alemmaksi $(589,709 \mathrm{~g} / \mathrm{d}) \mathrm{ja}$ rehuhyőtysuhde heikommaksi $(3.46,2.89 \mathrm{~kg} \mathrm{ka} / \mathrm{kg}$ lisăkasvua) Gasol-ohraryhmällă verrattuna kuivaa ohraa saaneeseen ryhmaaăn. Tulokset osoittavat, että menetelmä ei ole käyttökelpoinen normaalin terveen ohran säilömiseksi sikoja varten. Gasol-liuoksella on voitu vähentäă zearaleone-hometoksiinin haittavaikutuksia ja tăssä tarkoituksessa käsitellyllă viljalla sikoja ruokittaessa tulisi valkuaisen laatua parantaa esim. synteettisen lysiinin avulla. 